うに，フィブリルが互いに緻密にからみ合ってフィルムを成形し ている。フィルム中に脂質が含まれると，このフィブリル同志の 緻密なからみ合いを妨げ，従ってフィルムの機械的強度が低下寸 るものであろう。

$$
4 \text { 総 括 }
$$

鯨腱，兰晹，牛皮を脱脂精製して電気化学的方法によってフィ
ルムを成形した場合，フィルムの機械的強度として抗張力，耐圧 力, 引裂強度などは, 乾燥状態拈よび湿潤状態ともに著しく増大 することがわかった。また，逆に脱脂精製試料に脂質を添加して 同様にフィルムを成形すると明らかに機械的強度は減少すること がわかった。これらの結果から，脂質はコラーゲンフィブリル同 志のからみ合いを妨げるものと考光られる。

\title{
セルロース物 質の酵素加水分解反応の反応特性
}

(昭 和 45 年 7 月 13 日受理)

\author{
荻原 允隆*1・荒井健一郎*1・少本 将 登*2
}

\begin{abstract}
セルロース物質の酵素加水分解反応を反応速度論的に取扱うために，まず反応速度式に打けるパラメ一タ一を求める方法を検討 した。従来のほとんどの報告では還元糖の増加量からパラメーターを求めているが, 著者らの市販の粉末七ルラーゼ用いた実験 では加水分解生成物は主としてグルコース抢よびセロビオースであり，これらの割合が反応の経過とともに著しく変化することを 認めたので，還元糖の测定から反応速度を追跡することは妥当でないと推定した。次に，加水分解に拈けるセルロ一ス物質の重量 損失からパラメータ一を求める方法を検討し，24 時間加水分解後のセルロース物質の重量損失を反応速度とし, Michaelis-Menten の式を変形した Hofstee プロットを用いることによって反応速度パラメーターを精度良く求めることができた。さらにこれらの パラメーターがセルロース物質の微細構造の影響を受忛るこをを認めたので，このよ5なパラメーターを用いるセルロース物質の 微細構造の解析が可能であると推察した。
\end{abstract}

\section{1 緒 言}

最近，セルロース加水分解酵素セルラーゼに関する研究が多く 報告されているが，その大部分は酵素の挙動に着目したもので, 反応基質としては比較的取扱いやすいカルボキシメチルセルロー ス (CMC) や粉末セルロースなどが用いられている。この反応の 反応速度についてもいくつかの報告 ${ }^{1 \sim 5}$ があるが，従来の研究で は還元糖の増加量から反応速度を追跡した例が多い。著者らは市 販の粉末セルラーゼを用いてセルロース繊維の加水分解反応を不 均一系高分子反応の立場から検討してきたが，この加水分解に拉 ける可溶抄生成物がほとんどグルコースとセロビオースのみであ り, この両者の比率は反応の経過とともに著しく変化することを 認めた6) ので，還元糖の測定によって反応のパラメーターを求め る方法注必ずしも妥当ではないと推定した。そこで, 著者らは加 水分解汸けるセルロース物質の重量損失から反応速度パラメー タ一を求める方法を検討し, さらにこの方法を用いて二, 三の改 質したセルロース物質の加水分解速度パラメーターを求め, その

*1 Yoshitaka OGIWARA, Kenichiro ARAI 群馬大学工学部 高分子化学科：群馬県桐生市天神町.

*2 Masataka YAMAMOTO 三島製紙株式会社吹田工場：大 阪府吹田市御旅町.

1）雨村明倫, 照井堯造, 酘酵工学, 43，275，281 (1965).

2) 若沢 正, 丹羽富造, 一之瀬夙次, 田中辰雄, 酶酵工学, 41,40 (1963).

3) 松葉 豊, 醴酵工学, 41, 47 (1963).

4) W. Gilligan, E. T. Reese, Cand. J. Microbiol., 1, 90 (1954).

5) A. D. McLaren, Enzymologia, 26, 237 (1963).

6）荒井健一郎, 荻原允隆, 角田 正, 䋊維学会昭和 45 年春 期研究発表会講演要旨.
結果について考察しだ。

用いた市販の粉末セルラーゼは純度のあまり高いものではな く, また数種の活性, すなわらセルロ一ス鎖の末端からセロビオ 一ス単位を切り取る活性, ランダムにセルロース鎖を切断する活 性，七ロビオースをグルコースに分解する活性などが含まれてい ると考觉られる。したがって，酵素の反応性に重点を置いた理論 的取扱いはあまり意味がないと考觉られるが，藷者らはこの粗セ ルラーゼの主反応がセルロース鎖のランダムな切断にあることを 統計的に確かめており，このような混合物でも一定の組成を有す る限りそのセルロース㵶維の反応性に重点を置いた検討を行なう ことは十分意味があると考党た。

\section{2 実験}

\section{$2 \cdot 1$ 試 料}

試料としては溶解悪硫酸パルプを水中で離解し，水をアセトン で置換してから風乾したもの，拈よびこれを $40^{\circ} \mathrm{C}$ の所定濃度の 水酸化ナトリウム水溶液で 1 時間膨潤処理した後十分水洗したも のを湿潤状態のままで用いた。セルラーゼは市販の粉末セルラー ゼ「セルラーゼオノズカ P 500」をそのまま用いた。

\section{$2 \cdot 2$ 実験方法}

$2 \cdot 2 \cdot 1$ セルラーゼ加水分解 セルラーゼを $\mathrm{pH} 4.1$ の 1/10.規

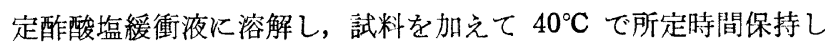
た後，煮沸によって反応を停止させた。つぎにグラスフィルター を用いて残椬を口別し，水洗した後， $105^{\circ} \mathrm{C} て ゙ 10$ 時間乾燥して 秤量した。

$2 \cdot 2 \cdot 2$ セルラーゼ加水分解における可溶性生成物の定量 ${ }^{6)}$ 加 水分解残渣の口液汇水酸化ナトリウム水溶液を加えて $\mathrm{pH} 7.0$ と し, 動物性半透膜を用いて 24 時間透析した後, 透析液を $30^{\circ} \mathrm{C}$ 
で減目濃縮した。この濃縮液を酢酸エチル一酶酸一水 $(3: 1: 3)$ 系 溶媒を用いてペーパークロマトグラフで展開し，各スポットの糖 を標準物質の $R_{f}$ と比較して同定した。これらの各スポットを水 で抽出し, Somogyi 法7)により還元糖として定量した。

$2 \cdot 2 \cdot 3$ 酸素反応における速度パラメーターの求め方 Michaelis-Menten の式（1）式を変形した Lineweaver-Burk プロッ ト（2）式にしたがって $1 / v$ と $1 / s$ をプロットするかままたは Hofstee プロット（3）式にしたがって $s / v$ とをプロットする ことにより得られた直線を外挿してみかけの Michaelis 定数 $K_{\mathrm{m}}$ と最大速度 $V$ を求めた。

$$
\begin{gathered}
v=\frac{V s}{K_{\mathrm{m}}+s} \\
\frac{1}{v}=\frac{1}{V}+\frac{K_{\mathrm{m}}}{V} \cdot \frac{1}{s} \\
\frac{s}{v}=\frac{K_{\mathrm{m}}}{V}+\frac{s}{V}
\end{gathered}
$$

ここで $v$ は反応速度， $V$ は最大速度， $K_{\mathrm{m}}$ は Michaelis 定数, $s$ は基質濃度をあらわ占。

\section{3 結 果と考察}

\section{$3 \cdot 1$ セルラーゼ加水分解における可溶性生成物}

著者らはセルロースの酥素加水分解に括ける分解生成物の阻害 効果を検詩してきたが，ペーパークロマトグラフで検出できる範 囲では還元性を有する可溶性分解生成物はセロビオースとグルコ 一スのみであることを認めた。さらにこの両者の比率は表 1 に示 すように経時的に変化し, またグルコースとセロビオースの阻害 物質定数が約 $5: 2$ と大きく相違していることを㽞めた。

Whitaker も分解生成物はグルコースとセロビオースの久であ ると報告している が，最終的には両者の比率が $1: 1$ になると 主張している点で著者らの結果と相違している。また Garrgg ら は少糖類の最少分解単位はセロトリオースであり，七ロビオース はそれ以上分解されないと報告している9 。これらの相違は主と して用いるセルラーゼの起源拈よび精製程度, 特にセロビア一ゼ の含有量の相違などに起因しているものと考えられる。

従来までのセルラーゼ加水分解反応の反応速度の検討には還元 力の増加を利用するものが多かったが，このような結果から本実 験の場合には䢬元力の增加を指標として反応速度を追究すること は適当ではないと推定した。そこで, 著者らは一定時間のセルラ

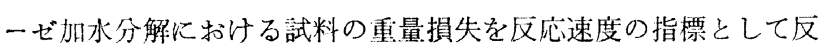

\begin{tabular}{|c|c|c|c|c|c|}
\hline & \multicolumn{5}{|c|}{ 处理時間 (hr) } \\
\hline & 6 & 12 & 24 & 48 & 96 \\
\hline グルロース(齐パルプ\%) & 1.65 & 2.7 & 7.4 & 11.6 & 21.2 \\
\hline セロビオース（対パルプ\%） & 10.15 & 13.5 & 18.1 & 26.0 & 34.6 \\
\hline 全重量椇失（奶パルプ％） & 11.8 & 16.2 & 25.5 & 37.6 & 55.8 \\
\hline 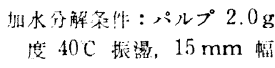 & $\begin{array}{l}\text { 七ルラー } \\
2 \text { 沚後 }\end{array}$ & $1.0 \mathrm{~g}$, & & & \\
\hline 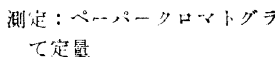 & 6行蟭一 & E抽出 & & & \\
\hline
\end{tabular}

表 1 溶解用亜硫酸パルプのセルラービ加水分解に打ける 可溶性加水分解生成物の組成

7）日本化学会編，“実験化学講坐（第 23 卷）生物化学 I”, 丸善 (1959), p. 413.

8) D. R. Whitaker, Can.J. Biochem. and Physiol., 34, 102 (1956).

9) P. J. Garregg, M. Han, Svensk Papperstidn. 72, 695 (1969).
応速庋パラメーターを求める方法を検討した。

\section{$3 \cdot 2$ 反応速度の測定}

一般の酵素反応では反応曲線の初期の直線部分から初速度を求 め, これを用いて各種パラメーターを求める。この初速度は酵素 濃度に比例する。しかし，一定時間の反応に打壮る重量損失を反 応速度とみなす方法では，短時間の反応に括ける重量損失を基準 にとると測定精度が非常に低く, 反応初速度を精度良く求めるこ とはできない。たと壳ば，図 1 に示すように 5 時間の反応に拈け る重量損失を反応速度としても, 反応速度とセルラーゼ濃度の間 に直線関係は認められない。また, 四 2 は処理時間を一定として 試料濃度の影響を検討したものであるが，試料濃度の高い活ど， またセルラーゼ濃度の低いほど初速度に近い反応速度の得られる ことが認められる。

これらの結果から, 反応速度の测定には重量損失の測定精度の 比較的良好な範囲でできるだけ短い反灾师間，低いセルラーゼ濃 度抢よび高い試料濃度を用いることが望杰しいことが明らかとな った。

\section{$3 \cdot 3$ 反応速度パラメーター}

図 3 にいくつかの処理時間に牤ける試料の重量損失と試料濃度 との関係を示した。これを速度パラメーターを求めるために比較 的多く用いられている Lineweaver-Burk プロットにとってみる と直線の精度が比較的低く, 反応速度パラメータ一を正確に求め

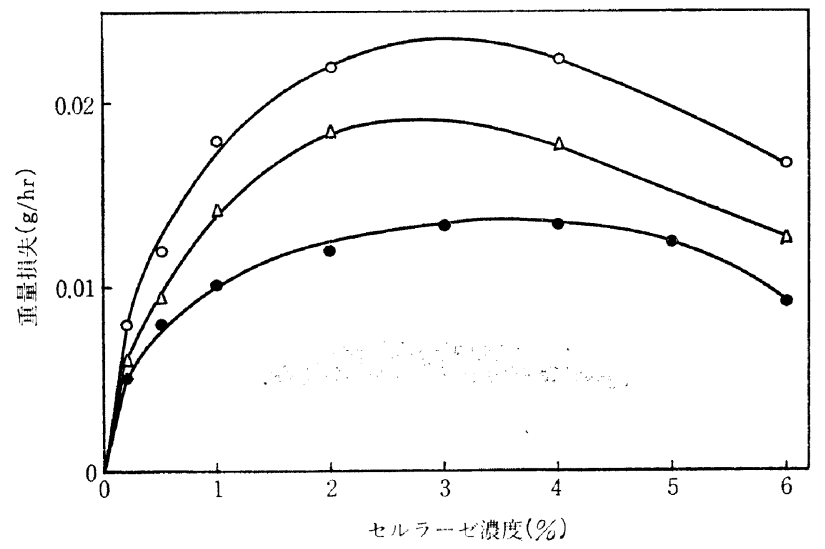

図 1 各種処理時間のセルラーゼ処理におけるパルブの 琶量損失とセルラーゼ濃度の関保

パルプ濃度 $1.0 \mathrm{~g} / 50 \mathrm{ml}$ 処理時間 $\bigcirc: 5$ 時間, $\triangle: 10$ 時閒。

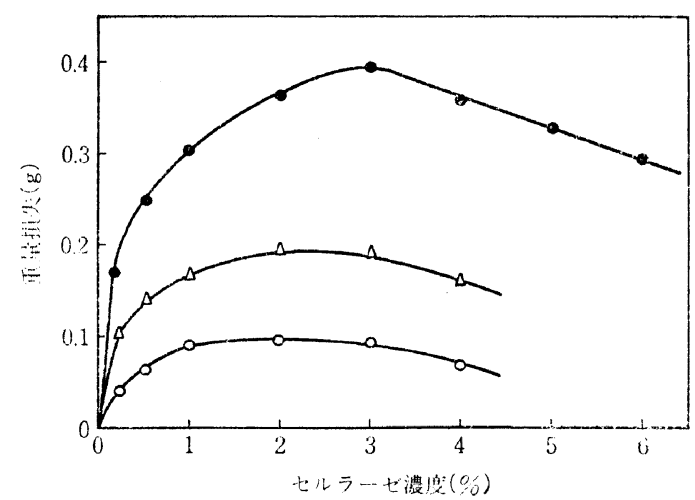

図 2 セルラーゼ処理に杉ける各種濃度のパルプの 重量損失とセルラービ濃度の関係

処理時間 24 時間

パルプ摵度 $\bigcirc: 0.25 \mathrm{~g} / 50 \mathrm{ml}, \triangle: 0.5 \mathrm{~g} / 50 \mathrm{~m} l, \bigcirc: 1.0 \mathrm{~g} / 50 \mathrm{~m} l$ 


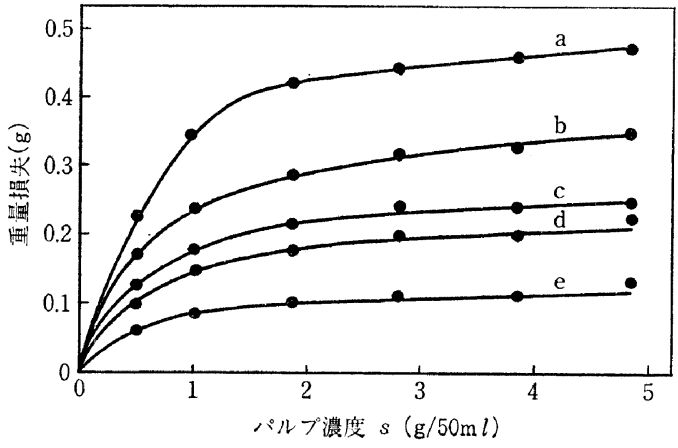

図 3 各種処理時間のセルラーゼ処理に和ける 重量損失とパルプ濃度の関係 セルラーゼ溜度 $1.0 \%$

処理時間 $a: 48$ 晆間, b : 24 時間, c : 15 時閒, d : 10 時閒, e : 5 時閒

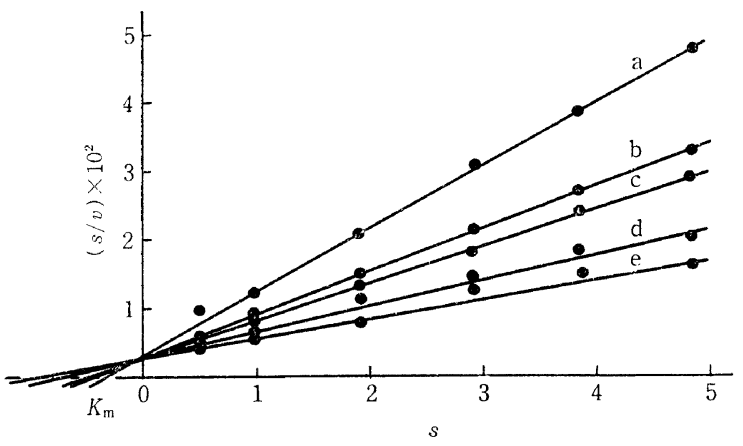

因 4 因 3 に示したデータの Hofstee プロット

ることはできなかった。これはこのプロットでは横軸に試料濃度 の逆数をとるために低濃度部分の值に比重がかかり，重量損失の 測定誤差が大きく影響した結果と考えられる。

図 3 のデータをHofsteeプロットにとると図 4 が得られる。こ の図では処理時間が 10 時間以下では直線の精度が比較的低いこ とが認められ，このバラッキは外插法でパラメーターを求めるの に大きな障害となる。しかし，処理時間を 24 時間とすればかな り精度良く直線を求め得ることが認められる。このように非常に 精度の良い值線が得られることはこの範囲では加水分解生成物に よる阻害効果を無視できることを示している。

つぎに，セルラーゼ濃度を変えた時の Hofstee プロットに拈け る直線の動きを検討した。理論的には最大速度 $V$ はセルラーゼ濃 度に比例して増大し， Michaelis 定数 $K_{\mathrm{m}}$ は一定にとどまるはず である。図 5 にセルラーゼ濃度を $0.1,0.5$ 牤よび $1.0 \mathrm{~g} / 100 \mathrm{ml}$ としたときの 24 時間処理に拈ける重量損失 $v$ とパルプ濃度 $s$ と の関係を示した。これを Lineweaver-Burk プロットにとってみ ると各直線の精度が低いために各直線が横軸上の一点で交差せ ず，反応速度パラメーターを正確に求めることができなかった。 図 5 のデータをHofsteeプロットすると図 6 が得られ，この場合 には 3 本の直線は完全に横軸上の一点で交差し，正確な $K_{\mathrm{m}}$ を求 めることができた。セルラーゼ濃度 $0.1 \%$ の場合の直線でバラッ キが大きいことは重量損失が少ないために実験䛊差の影響が大き くなった結果と考兄られる。また，酵素濃度 $0.5 \%$ では $s=1.0 \%$ 以下，酵素濃度 $1.0 \%$ では $s=2.0 \%$ 以下の範囲で直線からの偏 倚が認められる。また，表 2 に示すように Michaelis-Mentenの 式に打ける “ $K_{\mathrm{m}}$ はV $V 1 / 2$ に相当する速度を与える基質濃度に 等しい”という定義にしたがって求めた $K_{\mathrm{m}}$ と図6から求めた

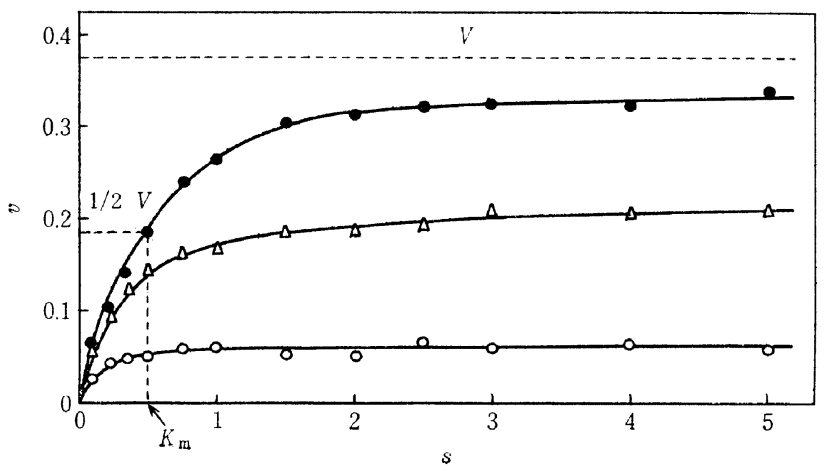

因 5 各種セルラーゼ濃度のセルラーゼ処理における 反応速度とパルプ濃度との関係 セルラーゼ浱度 $\bigcirc: 0.1 \%, \triangle: 0.5 \%, \bigcirc: 1.0 \%$

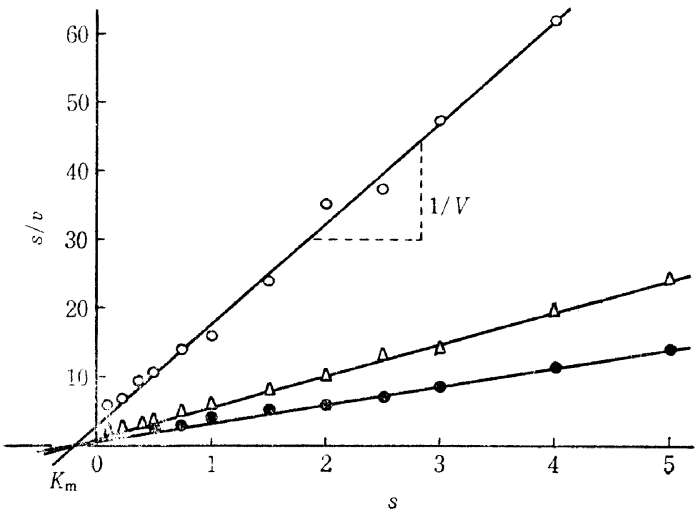

図 6 図5に示したデータの Hofstee プロット セルラーゼ涨度 $\bigcirc: 0.1 \%, \triangle: 0.5 \%, \bigcirc: 1.0 \%$

$K_{\mathrm{m}}$ がセルラーゼ濃度の高いほど相違する傾向が認められる。こ れらの結果はこれらの範囲では Michaelis-Menten の式の誘導の 基礎となっている “基質濃度が酵素濃度に比べて十分大きい” いう条件が満されていないことに起因すると推定できる。また， 反応速度はセルロース緎維の微細構造の影響をうけて経時的に低 下すると推定できるので $s$ 小さい範囲では全試料重量に対する 損失重量の割合が過大となって，24時間処理における重量損失 と定義した平均反応速度が低下することが考えられ，これも上述 の現象の一因となっているものと思われる。

このように，七ルラーゼ濃度の低いときに両方法により求めた $K_{\mathrm{m}}$ の值が一致することからも図 6 より求めた $K_{\mathrm{m}}$ の值の正確な ことが証明されていると考えられる。

ただし，セルラーゼ自体が数種の活性を含んでいると考觉られ ること拈よび初速度の代りに初期平均速度を用いたことなどから ここで得られた $K_{\mathrm{m}}$ および $V$ の持つ意味はかなり制約されている ことに留意しなければならない。しかし，これらの值が非常に高 い精度で得られ，また再現性も非常に良いことは重要な意味があ ると考党られる。

以上の結果から, セルラーゼ処理 24 時間の重量損失を反応速

表 $2 V$ から求めた $K_{\mathrm{m}}$ と図 6 から求めた $K_{\mathrm{m}}$ の比較

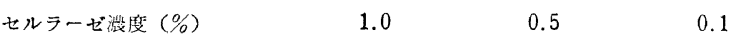

$\begin{array}{llll}V \text { から求めた } K_{\mathrm{m}}{ }^{*} & 0.53 & 0.28 & 0.20\end{array}$
四6から求めた $K_{\mathrm{m}} \quad 0.20 \quad 0.20 \quad 0.20$

* Michaelis-Menten の式に括いて $K_{\mathrm{m}}$ はVの $1 / 2$ に相当する速度を与克 る基質濃度と定義される。 
度としてセルロース濃度 $1.0 \%$ から 10\%をでの範井のデータを Hofstee プロットすることによって見掛けの $K_{\mathrm{m}}$ 扎よびVを精度 よく求められることが明らかとなった。

重量損失と反応速度とは直接的には関係がないよ5に見える が，実際には反応速度として単位時間当りの重量損失を用いても ほとんど矛盾がなく，現象的には十分意味を持っていると考えら れる。このよらな事実の理論的説明は現在検討中であるが，この ような手法は酸加水分解の場合にはしばしば用いられている。

\section{4 水酸化ナトリウム膨潤試料の反応速度パラメーター}

以上の方法によって求めた $K_{\mathrm{m}}$ 扰よび $V$ とセルロース物質の微 細構造との関連性を調べるために，8\% 打よび $12 \%$ の水酸化ナ トリウム水溶液で膨潤させた試料について遠心分離法による WRV ${ }^{10)}$ 和よび上記の方法により求めた $K_{\mathrm{m}}$ とVを測定した。結 果を表 3 亿示す。

膨潤量の指標である WRV が増加するにしたがって $K_{\mathrm{m}}$ およ び $V$ の増加する傾向が認められる。前報 ${ }^{10,11)}$ に挌いて, 著者らは

10) Y. Ogiwara, K.Arai, Textile Res.J., 38, 885 (1968).

11) Y. Ogiwara, K. Arai, Textile Res.J., 39, 422 (1969).
表 3 水酸化ナトリウム水溶液処理パルプの $K_{\mathrm{m}}$ 打よび $V$

\begin{tabular}{lccc} 
& $K_{\mathrm{m}}$ & $V \times 10^{2}$ & $\mathrm{WRV}$ \\
\hline 米处理パルプ & 0.39 & 1.58 & 67 \\
$8 \%$ 水酸化ナトリウム处理パルプ & 0.65 & 1.85 & 82 \\
$12 \%$ 水酸化ナトリウム处理パルプ & 1.00 & 2.66 & 92
\end{tabular}

この WRV と反応速度とは比例関係にあり，水酸化ナトリウム膨 潤試料では WRV 招よび反応速度はともに主として非晶部分の膨 潤量と密接な関係にあることを認めた。表 3 に打けるVの増加は セルロース物質の有効反応部分の量的な増加を反映しているもの と考光られるが， $K_{\mathrm{m}}$ は本来基質一酵素複合体の生成反応，逆反 芯扣よび分解反応の速度定数 $\left(k_{+1}, k_{-1}\right.$ 抢よび $\left.k_{2}\right)$ の比 $\left(k_{-1}+\right.$ $\left.k_{2}\right) / k_{+1}$ であり, 本報のデータのみでは $K_{\mathrm{m}}$ の増加を説明するこ とはできない。しかし，このよ5にセルラーゼ加水分解反応に拉 ける反念速度パラメーター $K_{\mathrm{m}}$ およびVがセルロース物質の微細 構造と密接な関係を示していることが明らか炕なっので，今後 これらの関係をさらに詳細に定量的に追求することによって多く の新しい知見が得られるものと推察される。

\section{ポリアミドの光伝導 性 ${ }^{* 1, * 2}$}

（昭和 45 年 7 月 14 日受理）

$$
\text { 公橋完・飛鋪靖 }
$$

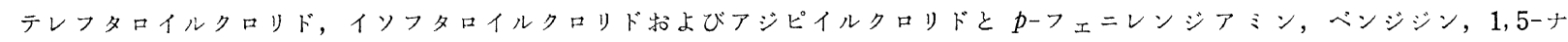

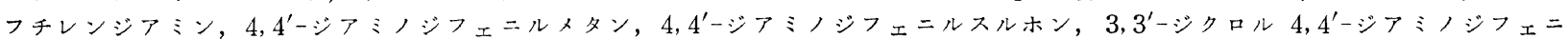
ルメタン，へキサメチレンジアミン，3,9-ビス(3-アミノプロピル)-2, 4, 8, 10-テトロキサスピロ $[5,5]$ ウンデカンとの重縮合反応 により得られたポリアミドの電気伝導性扣よび紫外領域の光伝導性が測定された。体積電気伝導の温度依存性の直線関係から有機 半導体の電気伝導の活性化エネルギー $\left(E_{\mathrm{A}}\right)$ が求められた。約 $200 \mathrm{~kg} / \mathrm{cm}^{2}$ で円板上に加圧, 成型された試料（表面積 1.307 $\mathrm{cm}^{2}$, 厚又 $\left.0.05 \sim 0.1 \mathrm{~cm}\right)$ が用いられた。テレフタロイル系 $\left(\rho=10^{12} \sim 10^{15} \mathrm{ohm} \cdot \mathrm{cm}, E_{\mathrm{A}}=0.20 \sim 1.11 \mathrm{eV}\right)$, イソフタロイル系 $\left(\rho=10^{6} \sim 10^{14} \mathrm{ohm} \cdot \mathrm{cm}, E_{\mathrm{A}}=0.35 \sim 1.54 \mathrm{eV}\right)$, アジピイル系 $\left(\rho=10^{8} \sim 10^{15} \mathrm{ohm} \cdot \mathrm{cm}, E_{\mathrm{A}}=0.08 \sim 0.87 \mathrm{eV}\right) 。$

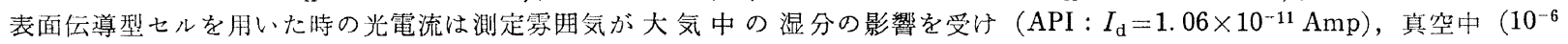
Torr）と此べて著しく小さい $\left(I_{\mathrm{p}}=4.36 \times 10^{-10} \mathrm{Amp}\right) 。$

暗電流化対する光電流の比が約 1000 以上あるものの構造依存性は次の傾向が得られた（括弧のなかの数字は比を示す）。

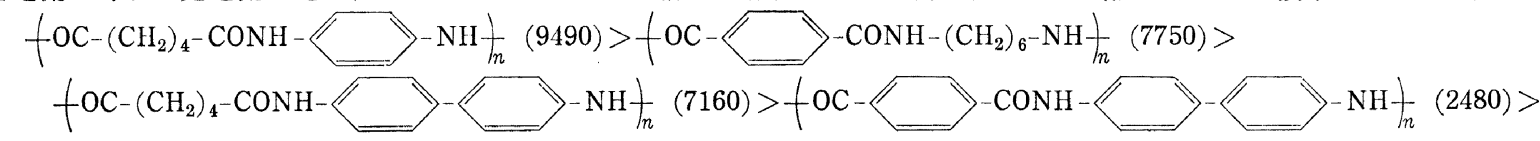

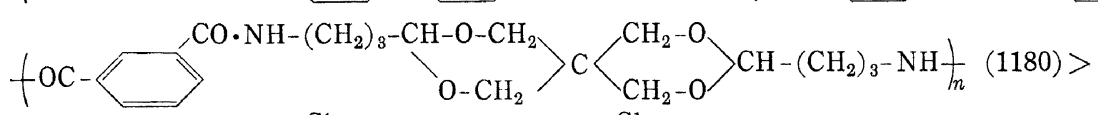

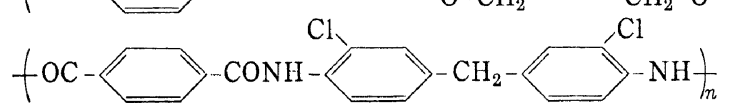

\section{1 緒言}

アミド絬合を主鎖に持つポリペプチドの電気伝導性は Eley 等 ${ }^{11}$ が中心蚆細倹討された。これらの伝導機構はアミノ基 からのプロトンによるイオン伝溥機構で説明されている。一方ア

\section{*1この報文を「電導性高分子物質に関する研究 (第 12 報)」 とする。}

*2 前報 (第 11 報), 工化, 73, 1881 (1970).

*3 Ryo HiRohashi, Yasushi HiShIKI, Masaaki DoHI 千 葉大学工学部写真工学科：千葉市弥生町.
ミノ基の水素結合が網状構造を形成することによる電子伝導も Andres ${ }^{2}$ が提案している。このよ5に伝導機構的にはイオン伝導 あるいは電子伝導のいずれの説とも現在論議されている ${ }^{3)}$ 。

有機化合物の電気物性の初期の段階から蛋白質の生物化学的興 味拈よび電荷の生体内での移動々の関連からポリペプチドの電気 伝導性が取り上げられている4)。ペプチド分子中のアミド結合は

1) D. D. Eley, D. I. Spivey, Trans. Faraday Soc., 56, 1432 (1960).

2) R. J. Andres, J. Polym. Sci., C (17), 213 (1967).

3) B. Rosenberg, J.Chem. Phys., 36, 816 (1967). 